DOI No: http://dx.doi.org/10.29228/Joh.49739

Authenticity process is conducted by

Makale Türü: Araştırma makalesi

intihal.net

Geliş Tarihi: 01-03-2021

Kabul Tarihi: 14-03-2021

On-line Yayın: 30-04-2021

Article Type: Research article Submitted: 01-03-2021

Accepted: 14-03-2021

Published Online: 30-04-2021

Atıf Bilgisi / Reference Information

Demirbaş, S. (2021). Mahmud II's Diplomatic Reforms and Final Ottoman Diplomatic Manoeuvres before The Battle of Nizip. Journal of History School, 51, 782805.

\title{
MAHMUD II'S DIPLOMATIC REFORMS AND FINAL OTTOMAN DIPLOMATIC MANOEUVRES BEFORE THE BATTLE OF NIZIP ${ }^{1}$
}

\author{
Serkan DEMİRBAŞ ${ }^{2}$
}

\begin{abstract}
Mehmed Ali Pasha problem took place between 1831 and 1839. In spite of the big ambitions of the governor of Egypt, Mehmed Ali Pasha who wanted to give the house of Osman an end, the two military defeats (1832 Konya and 1839 Nizip) did not finish off the Empire. At this point a question comes to mind: what saved the Empire that had already become militarily vulnerable from a certain collapse. The answer is simple: diplomacy. Most accounts of the Ottoman diplomacy of that era have always been one sided and Eurocentric due to some "orientalist" biases and prejudices. According to these narratives, after suffering some military defeats, Mahmud II and his diplomats just watched the diplomatic manoeuvres of the European powers in Ottoman lands and waited for the end without having any diplomatic plans and manoeuvres. They also portray Lord Palmerston as the sole architect of the 1840 Treaty of London that compensated the two military defeats and that prolonged the Empire for another century. However when we examine the instructions in Ottoman documents given by the Emperor to his diplomats residing in many European capitals and their efforts to follow them, it will be seen what kind of a role Mahmud II and his diplomats played in this diplomatic achievement. After

${ }^{1}$ This article is based on a chapter from my PhD thesis: Serkan Demirbaş, 'Mahmud II and Ottoman Diplomacy in the context of Mehmed Ali Problem (1832-1839): with special reference to the Ottoman Archives in Istanbul, (unpublished PhD Thesis, University of East Anglia, 2015).

2 Dr. Öğr. Üyesi, Eskişehir Osmangazi Üniversitesi Fen Edebiyat Fakültesi Tarih Bölümü, serkandemibas@hotmail.com, Orcıd: 0000-0002-0118-4169
\end{abstract}


Mahmud Iı's Diplomatic Reforms and Final Ottoman Diplomatic Manoeuvres Before...

a short introduction to the course of the institutional reforms in Ottoman diplomacy from Selim III to Mahmud II periods, this article focuses on the Empire's diplomatic manoeuvres prior to the Battle of Nizip that was itself an effort to bring the diplomatic campaign initiated by the Emperor and his men to a successful end.

Keywords: Mahmud II, Ottoman Diplomacy, Mehmet Ali Pasha Problem, The Battle of Nizip, Anglo-Ottoman Relations

\section{Mahmud'un Diplomatik Reformları ve Nizip Muharebe'sinden Önceki Son Osmanlı Diplomatik Manevraları}

\section{Öz}

Mehmed Ali Paşa Problemi 1831-1839 yılları arasında meydana gelmiştir. Osmanlı hanedanına son vermek isteyen Mısır Valisi Mehmed Ali Paşa'nın büyük hırslarına rağmen iki ağır askeri mağlubiyet (1832 Konya ve 1839 Nizip) Osmanlı İmparatorluğunun sonunu getirmemiştir. Bu aşamada askeri olarak korumasız bir hale gelen İmparatorluğun hayatını kurtaran etken ne olmuştur sorusu akla geliyor. Bunun cevabı çok basit bir şekilde karşımızda durmaktadır: Diplomasi. Lakin Osmanlı İmparatorluğunun kurtuluşuna sebep olan bu diplomasi hikayesinin anlatımı ise Oryantalist bakış açısının beraberinde getirdiği ön yargılar dolayısıyla hep tek taraflı, batılı devletler merkezli, yapılagelmiştir. Bu anlatıma göre II. Mahmud ve diplomatları aldıkları askeri mağlubiyetlerden sonra kendi topraklarında probleme müdahil olmuş Avrupalı devletlerin diplomatik manevralarını sözüm ona sanki pasif bir güç gibi izlemiş, hiçbir diplomatik manevraya ve plana sahip olmadan tabiri caizse kurbanlık koyun gibi sonlarını beklemişlerdir. Ya da bu iki büyük askeri mağlubiyeti diplomasi yoluyla telafi etmiş ve Osmanlı İmparatorlu'nun yaklaşık bir yüzyıl daha yaşamasına sebep olmuş 1840 yılında imzalanmış Londra Antlaşmasının tek mimarı meşhur İngiltere Dışişleri Bakanı Lord Palmerstone olarak gösterilmiştir. Halbuki; II Mahmud'un Avrupa'nın birçok başkentinde görevlendirdiği diplomatlarına verdiği direktifler ve bu direktiflerin bu yetenekli diplomatlar tarafından bütün zor şartlara rağmen uygulanma çalışmaları Osmanlı belgelerine dayanarak bütün ayrıntıları ile incelenirse, bu büyük diplomatik başarıda II. Mahmud ve Osmanlı diplomatlarının ortaya koydukları diplomatik mücadele ile az veya çok ne kadar paya sahip olduğu görülecektir. Bu çalışmamızda, bahsi geçen yıllarda ortaya konan diplomatik manevraların altyapısının daha iyi anlaşılması için önce kısaca belli bir oranda III. Selim'in ağırlıklı olarak da II. Mahmud'un Osmanlı Diplomasisinin Kurumsal yapısında meydan getirdikleri reform süreci özetle anlatıldıktan sonra, II. Mahmud ve Osmanlı diplomatlarının 1832 yılından beri ortaya koydukları diplomasi mücadelelerini başarılı bir şekilde nihayete erdirme gayreti olan Nizip Muharebesinden önceki son diplomatik manevraları bütün ayrıntıları ile mercek alınmaya çalışılmıştır. 
Anahtar Kelimeler: II. Mahmud, Osmanlı Diplomasisi, Mehmet Ali Paşa Sorunu, Nizip Muharebesi, Osmanl1-İngiltere İlişkileri

\section{INTRODUCTION}

From Mahmud's point of view, the right time had finally come for a particular move he had in mind which would put an end to all the trouble his rebel governor had caused. As a matter of fact his every diplomatic manoeuvre and order since the defeat at Konya, at the end of 1832, had been aimed in the direction of gaining British support, and at the same time handling the international position with regard to the Russians with great care. ${ }^{3}$ Simultaneously he was laying the foundations to enhance and reform the Empire in every respect: militarily, economically, administratively, and socially, by drawing upon European support and experience, especially that of the British. It is in this context that this article will examine in detail not only the Sultan and his statesmen's final preparations to enhance the army for the ultimate battle with Mehmet Ali's army, but also Mahmud's and his diplomats' struggle to solve the problem with diplomatically negotiated support from the British, as they had been trying to do since the outset of these difficulties. Nevertheless, the aim of this article is not to describe the final battle between the Sultan and his governor since this has already been done in detail by Turkish and English scholars. Subsequently, the main goal of this essay is to examine Mahmud and his statesmen's final diplomatic and military preparations, which involved the extensive use of diplomacy whilst at the same time enhancing the Empire with European support, particularly from the British, before the decisive battle with Mehmet Ali on 24 June 1839. For this reason this article will summarize true story of Mahmud and his statesmen's diplomatic efforts, by recounting their final political manoeuvres of 1838 and in the first half of 1839. In this respect, this essay will contribute to showing to what extent Mahmud II and his government

\footnotetext{
${ }^{3}$ Mahmud II's and his diplomats' primary objective was always to make an alliance with Britain against Mehmet Ali, even when he called the Russians to the Bosporus and made the treaty of Unkiar Skelessi with them. Many Ottoman documents confirm that the Russians were being used as a weapon to wake the British up to how important the Ottoman Empire was to the protection of British interests in the region. Of course, the Russians were, at the same time, a temporary solution enabling the Sultan to bring Ibrahim Pasha to a halt, as, until the implementation of the AngloOttoman alliance against Mehmet Ali and the Russians, he had been rapidly advancing with his army towards the heart of the Empire, Istanbul. Despite this pro-British atmosphere in this entire period, 1833-39, the weapon, Russia, had to be tactfully in the event of any possible repercussions from the Russians finding out they were being used. However, when looking at the related Ottoman documents, it could safely be said that Mahmud and his statesmen had been successful in their efforts on this matter.
} 
had had a role in bringing about in the European powers, particularly Britain, support for the Ottoman Empire in this fatal problem.

Before analysing the Ottoman diplomatic struggle and tactics to solve Mehmet Ali Problem, it would be useful to examine what Selim III and especially Mahmud II did to improve the Ottoman diplomatic institutions. Mahmud II initiated many reforms but the most important one with respect to this article concerns the developments in the Ministry of Foreign Affairs. In order to understand the infrastructure of Mahmud's and his diplomats' diplomatic struggle during the Mehmed Ali Crisis, 1832-1839, it is vital to be aware of the improvements in this Ministry.

\section{INSTITUTIONAL REFORMS IN OTTOMAN DIPLOMACY}

Modernist reforms in external affairs in the Ottoman Empire started with Mahmud's cousin, Selim III. He initiated permanent diplomatic missions in some of the European Capitals. Selim was eager to improve Ottoman diplomacy, so before he opened the Ottoman Embassies in Europe, his statesmen, under his guidance, discussed some important diplomatic issues with British diplomats. One example of this was the organisation of matters of state between the Ottoman Empire and each European Power, such as; which Ottoman official would match with which European official, which diplomatic appellation would be the most suitable for each new Ottoman ambassador, and which mode of travel, sea or land, would be the most suitable for diplomatic travel (Findley, 2014, p.148).

Selim had some significant reasons to improve diplomatic relations with European Countries. Turan crystallizes these reasons when he says that it was an obligation to be well informed about developments in Europe since matters were very volatile after the French Revolution. Another of Selim's reasons was that he was headed towards a policy of balance when it came to any developments in the Eastern Question, so it was necessary to get involved in the European decision process about the Ottoman Empire (Turan, 2014, p.286). In this respect, the first serious step came in 1793 when Yusuf Agah Effendi was sent to London as a first permanent Ottoman Ambassador (Findley, 2014, p.148; Turan, 2014, pp.288290).

Despite this significant diplomatic effort of Selim III's, there were some negative circumstances which would hinder his diplomatic success. Findley summarises these conditions saying:

"In the long run, however, Selim's attempts to establish permanent diplomatic and consular representation had only limited success. Lack of 


\section{Serkan DEMIRBAŞ}

qualification or interest among the vast majority of his subjects, the changeable diplomatic climate of the Napoleonic Era, the failure to create any central coordinating agency in Istanbul, and finally the period of reaction and uncertainty following Selim's own deposition and death, were so many obstacles to the continued development of his new systems." (Findley, 1972, p.395)

However, it is true to say that every diplomatic step Selim made was to positively affect Mahmud's diplomatic innovations and struggle.

There was another important diplomatic reform in the reign of Selim III which contributed to Mahmud II's Foreign Ministry reforms. This was to reform a vital office under Reis Effendi, ${ }^{4}$ called Amedi. ${ }^{5}$ According to Findley the reforms in this Office started with some regulations in 1797. Findley describes the duties of the Amedi Office's staff that they would accompany Reis Effendi to meetings with foreign ambassadors and were responsible for correspondence with these foreign embassies (Findley, 2014, p.92). The Office's importance rose after Selim sent permanent Ottoman ambassadors to various European Capitals, because the staff in this office was to establish a connection between Reis Effendi and the ambassadors in Europe. In addition to this, this office was to send coded messages to these ambassadors and decipher their secret reports as well (Turan, 2014, p.195). Clearly, this office was vital to the Ottoman Empire's diplomatic effort. However, it was not working well in the time of Selim III. Examining the reform programme in the Foreign Office is important in the understanding of the scope of Ottoman diplomatic ability in the Mehmed Ali Problem, because Mahmud's capable diplomats did not spontaneously appear in the 1830s. On the contrary, there was an effort, with successes and failures, by some Sultans, particularly Selim III and Mahmud II, to reform the Ottoman Empire's Foreign Affairs and the restructuring of the Amedi Office was one of these significant reforms.

In this respect, reports were presented to Selim concerning this Office. Two main problems were conspicuous in these reports. The first one was that the Office was overstaffed. Patronage was given as the reason for this problem. According to this report, the solution would be to ensure that nobody who was

\footnotetext{
${ }^{4}$ Reis Efendi had been working as the Foreign Minister of the Ottoman Government until Mahmud promoted Reis Efendi to Foreign Minister on March 1836. Too see the historical background of Reis Effendi look at C.V. Findley, The Legacy of Tradition to Reform: Origins of the Ottoman Foreign Ministry, International Journal of Middle East Studies, Vol. 1, No. 4 (Oct., 1970), pp. 334357

${ }^{5}$ Findley indicates that according to İnalc1k this office was established in 1777. Findley, Osmanl Imparatorluğu'nda Bürokratik Reform, p.92.
} 
unqualified for the job or over middle age would be employed at the office (Findley, 2014, p. 140-141). The second problem was one of lack of education of some of the staff at the Office. For this reason it was decided that the staff would be dismissed if they did not have the necessary educational background to fulfil the Office working conditions (Findley, 2014, p.144-145).

These instructions are significant because they are a sign of the Ottoman's intent to reform the Empire according to modern political principles and this effort made prior to his accession to power was to ease Mahmud's reform programme.

At this stage, it can be started to examine what Mahmud II did to improve his Empire's diplomatic system. As mentioned above, knowledge of this process would be useful, to understand the background of Mahmud's and his statesmen's diplomatic struggle during the Mehmed Ali Crisis.

First of all it should be known that centralization was the driving force behind all Mahmud's reform programmes. After the abolishment of the Janissaries in 1826 there was no longer any obstacle to Mahmud's reforms. In particular, some of the Empire's internal problems had become international problems during Mahmud's reign, such as the Greeks, and the Mehmed Ali Problem, and something would have to be done about these matters. However, the Ottoman Empire had very serious economic and military problems at that time due to the establishment of the new army, Asakir-i Mansure-i Muhammediye. The end of the Janissaries caused two problems; the first was that the Empire needed more financial resources to develop a new army, and the second was that the new army was so inexperienced. For these reasons there remained only one way forward, and that was diplomacy. Mahmud was to use diplomacy very well to help his Empire escape from these serious problems. He had to make the Empire's diplomatic institutions fit for the great diplomatic struggle to come.

The first attempt Mahmud made in this direction was to convert the official translators from non-Muslim to Muslim (Ortayl1, 2009, p.145). In accordance with this purpose he officially established Tercüme Odast, the Translation Office in 1833 (Zürcher, 2009, p.75). The Empire had naturally used many translators up to this date but a big problem related to the translators appeared in the 1820s. Since the eighteenth century the Rum Family members in Istanbul had served as the official translators of the Ottoman Empire (Zürcher, 2009, p.74). However, these translators had lost Mahmud's trust after the Greek Problem, and as a result of this doubt harboured by Mahmud they were discharged from this critical position. Findley illustrates this situation thus; 


\section{Serkan DEMIRBAŞ}

"In the spring of 1821, Constantine Mourouzi, then Translator of the Imperial Divan, was dismissed and executed on suspicion of complicity in revolutionary intrigues. Stavraki Aristarchi, thought to be more reliable though still suspect as a Greek, was appointed on a temporary basis (vekaletan) to take his place. Within twelve months, however, he also had compromised himself sufficiently with both Patriarch and Porte that he was dismissed and sent into exile." (Findley, 1972, p.400)

As can be seen in Findley's words, Stravraki Aristarchi was the last nonMuslim translator in the Empire. After Aristarchi's exile there was an interregnum period, until the official establishment of the Translation Office in 1833. In this period some Muslim translators, who were in fact "convert", had been assigned as the official ones. The first were Yahya Effendi and his son Ruhiddin (Ortayl1, 2009, p.145; Findley, 2014, p.155). ${ }^{6}$ Yahya Efendi was to be the first Muslim official translator and this was the first sign of the Translation Office, which was to have only Muslim Ottoman statesmen. He and his son were responsible for the translation of French and Romaic languages (Ortayl1, 2009, p.145). One of their most important missions was that of following European public opinion closely via the European newspapers and informing Mahmud II about the latest developments at that time. This is evidence that Mahmud had, as early as 1823 - ten years earlier than Mehmed Ali Problem, - been keen on having knowledge about developments in Europe and determining his diplomatic policies according to those developments. As it will be seen in the following parts of the article he was to do the same thing during the Mehmed Ali problem through the instrument of his diplomats. Findley quoted very explanatory words from Strangford Canning about this:

"M. Chabert [one of the dragomans of the British Embassy] called upon him a few mornings ago, and found him (Yahya Effendi) surrounded by a number of the young Turks whom the Porte has lately formed into a sort of Collegiate Establishment for the purpose of instruction in the European languages. They had a prodigious pile of the Frankfort Gazettes before them, and were busily engaged in translating indiscriminately, by the sultan's positive order, every Article in which the name or the Affairs of Turkey were to be found. His Highness will, assuredly, be not a little astounded on reading some of the paragraphs dated from Odessa - Augsburgh - and Nuremberg." (Findley, 1972, p.401-402)

${ }^{6}$ Findley gives Ruhiddin's name as Ruhu'l Din. 
Mahmud Iı's Diplomatic Reforms and Final Ottoman Diplomatic Manoeuvres Before...

Ultimately, after these ten years the Tercüme Odas1, Translation Office, was officially established in $1833 .^{7}$ This Office had a great importance to Mahmud's reforms because many significant political characters had been educated by experience at the Office, such as Mustafa Reşid Pasha, Ali Pasha, Fuad Pasha and others. Also the establishment of this office shows that Mahmud was decisive in determining his own diplomatic policies based on his own loyal Muslim diplomats, who would naturally struggle to defend the benefits of their own Empire. As can be seen in the article, Mahmud was to reap the fruits of this diplomatic reform during the Mehmed Ali Problem, particularly between 1834 and 1839, via his Muslim diplomats, who would endeavour to carry out the orders of their Sovereign in the European Capitals.

When considering both the diplomatic developments in the nineteenth century: the improvement of the Amedci Office and the establishment of Tercüme Odas1, it can be said that the Ottoman Foreign Office had been gaining a more Muslim identity day by day.

After these positive developments Mahmud thought that it was the right time to reopen the permanent Ottoman diplomatic Embassies in the European Capitals. After Selim's death the Ottoman Embassies, which had been opened in his time, lost their significance. Mahmud had many diplomatic plans. In fact, he was obliged to do so, since as mentioned the only remaining way to rescue the Empire was diplomacy, and therefore he needed to have far-reaching plans, which would be able to protect the Ottoman benefits in Europe. As a result of this opinion he reopened the Ottoman Embassies. The first significant diplomatic representatives were Mavroyeni, Mustafa Reşid Pasha, Namık Pasha, Fethi Pasha (Findley, 1972, pp.404-405). All of them were to take an important place in Mahmud's diplomatic game between 1832-1839.

Despite all of these positive developments in foreign affairs there was still need for reform in foreign affairs. As mentioned above Reis Effendi was responsible for the Empire's foreign affairs, however the modus operandi was still almost the same at the beginning of the 1830s as it had been in the classical ages of the Ottoman Empire. Thus the modern foreign state organisation would have to be established as soon as possible to fulfil the conditions of this modern age.

${ }^{7}$ To find detailed information about the Translation Office see Findley, The Foundation of the Ottoman Foreign Ministry: The Beginnings of Bureaucratic Reform under Selim III and Mahmud II, pp. 401-408, Findley, Osmanlı İmparatorluğu'nda Bürokratik Reform, pp. 155-158, Ortayl1, Imparatorluğun En Uzun Yüzyll, pp. 145-146. Turan, Imparatorluk ve Diplomasi, pp. 349-351. 


\section{Serkan DEMIRBAŞ}

Thereupon the expected step was taken by Mahmud and he turned Reis Effendi into the Foreign Ministry on 11 March 1836 and the last Reis Effendi, Akif Effendi, became the first Foreign Minister of the Ottoman Empire (Turan, 2014, p.352). As Turan mentioned, this step was not only a change in the name of this position in the government. Mahmud had also changed the structure of the old Office and the new structure of the Foreign Ministry had been prepared according to modern international conditions at that time. ${ }^{8}$

After looking at Mahmud's mentioned reforms with regard to the main topics of this study, we can start now to examine in detail what Mahmud II and his diplomats did before the battle of Nizip diplomatically to resolve one of the biggest problems the Ottoman Empire had faced up to that time, the Mehmed Ali Problem.

\section{OTTOMAN DIPLOMATIC STRUGGLE BEFORE THE BATTLE OF NIZIP}

1838 was a crucial year for Mahmud to make the final provisions for his plans to win all the available diplomatic support to his side and at the same time, as far as possible to make his army ready for the anticipated battle against his rebel governor's forces. Concerning this, he ordered on 20 February 1838, that Mustafa Reşid Pasha, who was the Ottoman Foreign Minister at that time, should be sent to France as the Ottoman Ambassador; and Ahmed Pasha, the governor in Aydin, should also be sent to Britain as the Ottoman Ambassador (BOA, HAT., $380 / 20558$ C). According to the instructions he gave, the main aim of these appointments was to negotiate with the British and the French about Mahmud's final plan with respect to the Mehmet Ali problem. Mahmud was aggrieved that Mehmet Ali was violating the treaty of Kutahya every day, with his army relentlessly advancing towards to the provinces which were not in his jurisdiction. However, by shrewdly registering his protest with these countries he was paving the way for their understanding and approval in the eventuality his own forces had to make the first strike against Mehmet. Mahmud was planning to attack Mehmet Ali's army in Syria, Aleppo, in the autumn of 1838 (BOA, HAT., 380/20558 C), and by ensuring the European Countries knew Mahmud was the injured party, he could feel more confident of their support when the critical time came. In this respect, these two Ottoman Ambassadors were instructed to strive

\footnotetext{
${ }^{8}$ For more detailed information about the restructuring of the Ottoman Foreign Ministry after 1836 see Ortaylı, Imparatorluğun En Uzun Yüzyıl, pp. 146-148, Turan, Imparatorluk ve Diplomasi, pp. 351-355.
} 
Mahmud Iı's Diplomatic Reforms and Final Ottoman Diplomatic Manoeuvres Before...

to induce both these countries to pledge him their support and win their approval for the intervention of the Central Government should the situation demand (BOA, HAT., 380/20558 C). It seems that Mahmud did not want to wait any longer to see the fruits of his diplomatic labour; with which he had been carefully preparing the way ahead since the beginning of 1833. However, the Ottoman statesman responsible for these last preparations for the battle reported that although this plan was applicable, when the time came, with acceptance from both countries, at the same time more work needed to be discreetly undertaken in order to augment the quantity of ammunition accessible by the army.

Mahmud II also made known to the relevant parties that if Mehmet Ali did not content himself with the provinces that he had obtained with the treaty of Kütahya, and if he attempted to challenge the Central Government and requisition even more of the lands which were not currently under his control, such as Bagdad or any other province, then this act would mean that the first act of aggression had come from him not from the Sultan, in consequence of this provocative manoeuvre by the Pasha. Mahmud went on to tell his diplomats that Britain and France should be ready to acknowledge that the Sultan had the right of intervention when it came to restraint of his rebel governor (BOA, HAT., 380/20558 C). Mahmud's persistence, it seemed, was continuing to win British favour to his side in 1838, just as much as it had done in 1833 and Mahmud knew very well that first and foremost, he would have to prepare Palmerston to support the eventuality of a possible intervention, since Palmerston had not previously been very supportive of the idea of Mahmud's attacking Mehmet Ali without the Egyptian army making the first move against the Sultan's army. In this context Rodkey recounts that Palmerston said Britain:

"would undoubtedly assist him to repel any attack on the part of Mehemet Ali, it would, on the other hand, be a different question if the war was begun by the Sultan"(Rodkey, 1929, p.590)

Rodkey also has explained the reason for this opinion of Palmerston's in that:

"until the renewal of war between the Sultan and the Pasha of Egypt in 1839 Palmerston consistently counselled the Turkish government to keep the peace in the Levant in order that it might succeed with its plans for military and administrative reorganization, and on more than one occasion he took practical steps to further Ottoman reform." (Rodkey, 1929, p.576-577) 


\section{Serkan DEMIRBAŞ}

For these reasons Mahmud was aware that he needed to find reasonable and acceptable grounds to attack to his rebel governor should the occasion arise; he seems, however, to have assumed that if he had such grounds, the British would come to his aid if needed, an assumption based on his hopes that his armies were superior to those of the rebel Pasha. It would take the failure of the second assumption - and an international crisis - to produce such intervention.

Mahmud also indicated in his rescript that all statesmen should make the utmost efforts to dispel and repel all hazard and damage from Mehmet Ali, however he took pains to reassure them that Mehmet Ali would not dare to attack to any district which was under the Central Government jurisdiction. Nonetheless, these precautionary preparations, he continued in his orders, should be calmly made by laying down the suggested defensive preparations (BOA, HAT., 380/20558 C). In response, the governor of Urfa requested from the Sultan that any ammunition from the other further out provinces should be immediately transferred to Baghdad and to the cities near to it, as this was the nearest populated area to his advancing troops. This was vital, he added, since he had received news from Egypt that Mehmet Ali had established nine new regiments in Egypt and also at the same time the Pasha had sent the troops he had in Damascus to Egypt as well, and lastly, on top of that he had dispatched his generals to Aleppo and nearby cities (BOA, HAT., 380/20558 C). Mahmud and his statesmen had been careful to follow all Mehmet Ali's moves very closely. In this case, the report about the governor was extremely detailed in all the latest developments and the activities he made in the region. For obvious reasons was is very useful to Mahmud and his statesmen to be well informed about all Mehmet Ali's recent activities and also extremely informative to the observer to be able to see such detailed troop movements and appreciate how the Sultan responded. According to this report, the Egyptian troops had recently been dispatched to Gülek, a district in the South Mediterranean, by Mehmet Ali. There they were defeated; a proportion of them were killed and the rest of them had to retreat from the region. Thereupon, Ibrahim Pasha, the son of Mehmet Ali, took along almost five regiments of troops from Aleppo and attacked Gülek again. There were several reasons for Ibrahim's attack Gülek from the governor of Urfa's point of view: one of them could have been that he wanted revenge for the previous defeat in Gülek, or perhaps one of them was that Mehmet Ali wanted to distract the European Powers from his latest secret military preparations in the region. A third possibility was that he might have had the intention to first withdraw to Damascus, regroup, and then move towards Basra or Bagdad (BOA, HAT., 380/20558 C). 
On the occasions when Mehmet Ali was defeated, Mahmud was of course pleased. However, he warned his statesmen that they should not be deceived by Mehmet Ali's latest protestations that he only really wanted peace. Mahmud was not taken in by these claims, and warned his government that Mehmet Ali would not give up on his real aims so easily and the only reason for this temporary appearance of peace-making was to give him time to regroup after his army's latest debacles in various locations (BOA, HAT., 382/20584). He also stated in his rescript that Mehmet Ali was obliged to appear to be conciliatory, since the European powers had changed their opinion about Mehmet Ali after they saw his defeats; but this facade was only one of Mehmet Ali's tricks and was bound to be short-lived. Mahmud's wording started to become sterner and more direct as he continued with the observation that now everybody could understand how Mehmet Ali had betrayed his religion, and was a traitor to his state, and therefore if anybody had ever trusted him, they could clearly no longer do so. Finally, Mahmud ordered that for all these reasons, all the preparations against Mehmet Ali that he had recommended should be made, but nevertheless, until the right time came no direct action should be taken against him (BOA, HAT., 382/20584). Mahmud seemed to be determined to completely resolve his biggest problem this time. In accordance with this purpose, he put all his efforts into optimizing both the diplomatic conditions, and his army's readiness, for war.

After the Sultan's order, the governor of Urfa reported that actually he had already been ceaselessly undertaking secret military preparations, even prior to the order. In this respect, he had established sixteen battalions of "redif" " 9 troops and six battalions of redif artillerymen from Sivas, Diyarbekir, Urfa, and some other cities, and dispatched them to the Bagdad region (BOA, HAT., 380/20558 C). All of these reports show that both sides, Mahmud and Mehmet Ali, had been careering towards a confrontation in battle at a great pace, yet at the same time both sides were seeking to win diplomatic support to their side during this process.

On the Central Government's side, preparations did not only involve the establishment of the new redif troops, but also a drive to increase the amount of available ammunition, and additionally, efforts to fulfil other deficiencies with respect to army equipment had also continued unrelentingly. In this respect, the governor indicated that the soldiers' raincoats and clothing, made in white cloth because it was spring, should be supplied and also, he added, three hundred dirhams, a kind of the Ottoman money, for food for the soldiers, and from ten to

\footnotetext{
${ }^{9}$ Redif means those Ottoman troops who had completed their mission in the army, after which they were on standby to be recalled to the army.
} 
twenty para, another form of Ottoman currency, should be given to the soldiers as their salary (BOA, HAT., 380/20558 C).

As agreed in the Treaty of Kutahya, Mehmet Ali took on the responsibility of administering Syria and Adana as well as Egypt. However, after the signing of the treaty, he took the privileges the treaty offered and, disregarding its terms of restraint, started to attack to the cities which were under the Sultan's control, such as Urfa, and Maras. Due to this aggression, the governor of Urfa stated in his report that because of the close proximity of Mehmet Ali's troops to his city, he also had established three redif battalions, and five hundred Ottoman soldiers had been assigned to Urfa in order to drill these redif troops (BOA, HAT., 380/20558 C). In addition to these precautions, the governor stated that if Mehmet Ali's army did attack Urfa, they would also need eight thousand pouches of Akçe, the Ottoman currency, in order to meet the army's requirements for supplies.

Following on from these developments came an extensive report with respect to the latest situation of the Mehmet Ali problem, in terms of the diplomatic conditions. This was presented to Mahmud II (BOA, HAT., 382/20584). According to the report, the European powers, most notably Britain, were beginning to manifest their true opinions about Mehmet Ali Pasha and they were clearly in favour of the Ottoman Empire. In this respect, Ponsonby sent a diplomatic note to the Pasha stating that it was his duty as a governor to pay his eighteen months accumulated tax liabilities to the central government, and not to keep them for his own purposes. This show of support for the Ottomans, and international condemnation of Mehmet Ali Pasha was very useful, the report said, in terms of political benefits and advantages (BOA, HAT., 382/20584).

The complex diplomatic situation between the Sultan and the Pasha had been developing rapidly, as the end of the problem approached. In this context, the Ottoman statesmen had started to watch Mehmet Ali's actions very closely. In accordance with this purpose some Ottoman officials had been assigned to monitor the Egyptian Fleet's movements in and out of the Egyptian harbour which enabled a detailed report to be prepared and presented to the Marine Minister. After this report, Central Government ordered that no concessions or assistance should be given to Mehmet Ali over any land occupation or harbouring his fleet and he would be most insistent on this matter, because carrying out this order would effectively block any sedition (BOA, HAT., 382/20584). This order, following closely after monitoring the movements of Mehmet Ali's vessels had not only been about curbing Mehmet Ali's armada but also applied to the activities of sympathetic Ottoman officials, who had been secretly supporting Mehmet Ali. One of them was the Major General of Maras, a city in the East; 
Süleyman Pasha. It was understood that he was a supporter of the rebel governor and therefore it was imperative that he should be excluded from Maras forthwith. Hafiz Pasha was appointed to carry out this mission (BOA, HAT., 382/20584). This time, Mahmud was being very cautious and rigorously scrutinising the problem from every possible angle, trying to pre-empt every possible mishap.

In addition to all these preparations Mahmud wanted to improve his army's technical infrastructure by taking advantage of the expertise and availability of foreign army officers. Ottoman Empire reform process describes, initially a lot of British officials were brought to the Empire to enhance and educate the new and inexperienced Ottoman Army. However, later on, Mahmud and Palmerston desisted from further usage of foreign army's officers for training purposes Mahmud had only wanted these British Officers to educate the Ottoman officers in training techniques and improve the army in its ability to utilise technical equipment; but Palmerston, conversely, had wanted his officers to occupy permanent positions of command within the Ottoman Army. Therefore, Mahmud had turned to the Prussian officers as a more suitable source of the assistance he was looking for, and started to bring some of them over, in order to prepare the Ottoman Army for the last and biggest battle against Mehmet Ali (BOA, HAT., 382/20584).

Meanwhile, the practice of strengthening friendly British relations through private connections with the more influential members of society had increased, so that more British support could be mustered before the final battle. In line with this purpose, Mahmud sent a necklace studded with valuable precious stones to both the Queen Victoria and her mother. As an interesting aside about the necklace; there was an Ottoman coin, which was made from a valuable Turkish stone, called Akik Taşı, placed in the middle of the necklace. On this coin were written some Turkish words. This was done because Ottoman money was much in demand and highly respected in Europe at that time (BOA, HAT., 382/20584). In addition to this, some Turkish furs and tapestries were sent to the Queen and her mother and a number of British ministers were also sent some gifts (BOA, HAT., 1179/46569 J). These gifts were only small tokens but as Palmerston had assured, when he sent five horses as a gift to the Sultan in the name of the King a few years ago that "these horses were not so valuable themselves in financial terms but they would be a strong evidence to show Mehmet Ali and the Russians that Britain would stand by the Ottomans' side in all circumstances. "(BOA, HAT., 1190/46879 001). Now it was the Ottoman's turn to show Mehmet Ali and the other powers, with their token gifts that the British were with them to help resolve any problems. 


\section{Serkan DEMIRBAŞ}

Meantime, as a matter of course, diplomatic relations between the Ottoman Empire and the other European powers had been ongoing in the context of the Mehmet Ali problem. One of the most significant parties on the diplomatic scene was Metternich. The Austrian Ambassador in Istanbul informed the Ottoman Government that Metternich sent a message to Mahmud II suggesting that he decrease his latest military preparations against Mehmet Ali. Metternich also made a most surprising offer: to resolve the Ottoman's problem without having to go to war (BOA, HAT., 381/20567). It seems that Palmerston was not alone in feeling anxious about the prospect of disrupting European peace with a war between the Sultan and his governor. Interestingly, Mahmud responded to this offer saying that if Britain would join in with this possible attempt at an alternative solution as an allied country, he was inclined to accept this offer and told the Austrian Ambassador that he could indicate this response thus to Metternich (BOA, HAT., 381/20567). This response is more evidence demonstrating Mahmud II's strong desire for cooperation with Britain to solve the problem. Although all recent signs indicated that Mahmud was gearing up to eradicate his biggest problem with a final decisive battle, it seems that he had been weighing up the international balance of power and waiting until the time was right to employ an alternative solution.

At this stage, analysis of the latest diplomatic developments from the point of view of the Ottoman side shows that all Mahmud's and his diplomats', efforts since the beginning of the problem had finally started to yield their results. By the time 1838 came around, it seems that there was no longer any feeling of hesitancy in the majority of the British with regard to supporting the Ottoman Empire. By way of example, when the Ottoman Prime Minister and Ponsonby had a meeting, they decided to join the Ottoman and British Armadas in the Lesbos and Chios to make a stronger force against Mehmet Ali. In this meeting Ponsonby asked the Prime Minister if in the eventuality of a war occurring between Central Government and the rebel governor, and if the Russians offered to help Central Government by sending the Russian fleet and troops to the battlefield, what would the Ottoman government to do about this offer? (BOA, C..HR., 152/7569) The time had come for Palmerston and Ponsonby to find out from Mahmud II and his ministers their opinions on whether, in their minds, the conditions of the treaty of Unkiar Skelessi had lost their validity or not. In fact, the abolition of the treaty of Unkiar Skelessi was Palmerston's single most important aim in Eastern affairs. ${ }^{10}$

${ }^{10}$ To see the vital treaty from a different perspective than the literature look at; S. Demirbas, A New Perspective on the Treaty of Unkiar Skelessi Mahmud II's Use of International Diplomacy to 
At the same time, Britain had also started to make efforts to encourage the other powers in Europe to approach the Ottoman Government with help to solve the problem in diplomatic ways. In this respect, the British agreed to share their significant privileges, which had ensued from the treaty of Balta Limani, 16 August 1838, with the other European Countries, in order to create an alliance against Mehmet Ali. For example, the Ottoman Ambassador in Vienna, Mehmet Rifat Bey, reported that Queen Victoria had stated in her speech on the opening day of the British Parliament that a commercial treaty with the Austrians, much like the treaty of Balta Limani would be very useful and beneficial for Austria, Britain and the Ottoman Empire (BOA, HAT., 685/33266 H). In the same vein, the old rivals in the Levant, Britain and France, had celebrated a commercial treaty signed together with the Ottoman Empire, with a banquet prepared by the Ottoman Government (BOA, HAT., 737/34965 E).

Meanwhile, the Ottomans continued to prepare their Army for the imminent battle with the Egyptian Army. In accordance with this purpose, they put in an order with Britain, France and Russia for body armour/uniforms (BOA, HAT., 697/33630).

As mentioned above, the Ottoman Fleet had started to act jointly with the British Fleet in the Mediterranean Sea. Unsurprisingly, the Russians found this a most irksome state of affairs. By way of example of this, the Prussian Ambassador in Istanbul communicated to the Ottoman Foreign Minister that the latest manoeuvres of the Ottoman Fleet along with the British war ships around Izmir, (an Ottoman city in the Mediterranean) was making the Russians anxious (BOA, HAT., 737/34969 G). It seems that Mahmud felt he could now gradually start to leave aside being careful not offend the Russians, as he had had to do for so long when he was striving to make the Anglo-Ottoman Alliance possible. His real diplomatic plan's true colours had begun to come out. Moreover, news had even started to appear in the British Press that if Mehmet Ali's army started a war against the Central Government, it was planned that the British Fleet would go to Alexandria to prevent the Egyptian army from causing any harm to the Ottoman Empire (BOA, HAT., 828/37478 A). Such rumours abounded, and encouraged Mahmud II to think that if he did act, the British would be on his side.

These feelings were increased by reports from the Ottoman ambassador in Prussia, Kamil Pasha, who informed Istanbul that Britain had given formal notice to Mehmet Ali that the British supported the territorial integrity of the Ottoman Empire and not his anarchic endeavours (BOA, HAT., 828/37482 A). The British

Resolve the Mehmet Ali Problem, Eskişehir Osmangazi Üniversitesi Sosyal Bilimler Dergisi, 17(2), Eskişehir December 2016, pp. 1-16. 


\section{Serkan DEMIRBAŞ}

Government wanted to reassure Mahmud and his ministers and in this respect, they also indicated to the Ottoman Ambassador in London, Sarım Effendi that the British would always be on the Ottoman side and continue to support them in their struggle against the Egyptian problem (BOA, HAT., 828/37490). At the same time, Reshid Pasha, the Ottoman Foreign Minister, had been attempting to create a public opinion in Europe against Mehmet Ali by getting in touch with the European Powers (BOA, HAT., 829/37498). From the Topkapi Palace, the view was looking favourable for a time of reckoning with the over-mighty governor of Egypt.

But Mehmet Ali had not been sitting by idly and watching Mahmud's diplomatic manoeuvres; on the contrary, he continued to be diplomatically active as well. He started to openly declare that he would not desist from seeking to gain his independence. Palmerston, although he was out of London at the moment, sent a letter to Sarım Effendi about this bold announcement, saying that Mehmet Ali's last declaration had been made in order to find out how the European Powers would react, and when he got back to London he would like to meet and negotiate about this topic in detail with Sarım Effendi (BOA, HAT., 829/37500 B.). Sarım Effendi reported after completing his round with his contacts among the British politicians in London that the British had a good mind to resolve the problem for the benefit of the Ottomans (BOA, HAT., 830/37506). Another diplomat aside from Sarım Effendi, who had been very active in this process, was Kamil Pasha in Prussia. He met with the British Charge D'affaires in Prussia in order to find out what was happening with respect to the latest negotiations in the British Government about the Mehmet Ali problem (BOA, HAT., 829/37502 B). All of this active enquiry-making from the Ottoman diplomats show that they had been working hard under the Sultan's direction to successfully achieve their objective of resolving the problem with the help of the British.

Ibrahim Pasha, had also been watching developments and preparing for war. He, too, had been determined to enhance his army in preparation for the last battle. In this context, he tried to gather some weapons from the Dürzi people, a kind of religious community in the Ottoman Empire, but they refused to give up their weapons to Ibrahim and fought against him (BOA, HAT., 381/20579 H).

The diplomatic complexities increased as events moved towards crisis. For instance, although Britain and France had sternly warned Ibrahim Pasha to not attempt any kind of attack upon the Central Government's troops, at the same time these two powers gave notice to the Central Government that if the Russians assisted the Ottoman Government, then they would support the opposite side: Ibrahim Pasha (BOA, HAT., 381/20579 H). All players in the game seemed, as 
it were, to place their last diplomatic card. But if the Europeans thought that they had the power to prevent the actors in the East from pursuing their own plans they were, not for the first or last time, over estimating their influence. However, the Ottomans were seeking to use the Chancelleries of Europe as much as the latter were trying to use them.

The Ottoman Empire had been very sensitive to the diplomatic balance between all the countries in the region as well. Although Mahmud II and his diplomats had been striving to gain British support, they had also been endeavouring not to cause the Russians to have misgivings about their true aims. This extreme sensitivity can be seen in the curious matter of an article containing positive points about the Sultan. It was printed by the Ottoman government, and would have been reproduced in the British newspapers but for the fact that when Mahmud saw the article he adjudged it to be unsuitable for publication in that form, in case the Russians might see the Sultan effectively being praised by Britain and be offended at the cordial relations the article implied. For this reason, Mahmud ordered his ministers to have the style of the article softened so as not to be so effusive. Consequently, a British official was assigned to submit the new version of the article to the British newspapers (BOA, HAT., 382/20592). In the light of this example it could be said that Mahmud II and his skilful diplomats were not just basing their diplomatic policies on only one possibility, on the contrary, they were aware that they had to consider all possibilities in this diplomatic struggle, from all angles.

It was in this context that Mahmud II ordered his ministers that they should be very careful about the latest diplomatic process in Europe and they should use the correct language when the right times came in order to ensure the European powers' support of the Ottomans concerning the Mehmet Ali problem (BOA, HAT., 452/22409 C).

Meanwhile, Sarım Effendi delivered a secret report from London that he had met with Palmerston. This report stated that Britain was of one mind with the Sultan about the Mehmet Ali problem, and they would not in the least support Mehmet Ali in his struggle for independence (BOA, HAT., 831/37519 A). Sarım Effendi also indicated from London that after this meeting Palmerston sent a letter to Campbell, the British Ambassador in Alexandria, that Britain would not in any sense consent to, encourage or uphold Mehmet Ali's separation from the Central Government (BOA, HAT., 831/37519 B). This was just the kind of unequivocal support the Sultan had been working towards, and a far cry from the initial lukewarm response he had received at the outset. 


\section{Serkan DEMIRBAŞ}

At the same time as these diplomatic developments, there were two significant developments in the second half of the 1830s that had put the AngloOttoman relationship on a very good footing. One of them was the Treaty of Balta Limani and the other was the Anglo-Ottoman cooperation to reform the Ottoman Empire and enhance its infrastructure. In particular, Mahmud wanted to use the Treaty of Balta Limani to completely win the British on his side, despite there being many negative features within the treaty which would straiten, somehow, the Ottoman economic life. ${ }^{11}$ Moreover, the cooperation between the British and the Ottomans in the reform process to strengthen the Empire against Mehmet Ali and the Russians, resulted in much-improved Anglo-Ottoman relations. Mahmud also took the advantage of the positive diplomatic atmosphere in his Empire's favour to reform his Empire by rallying European support in this process, which was one of Mahmud II's most important goals.

With these last positive diplomatic developments, even though Palmerston and Metternich's apprehension about preventing the shattering of European peace had been on the agenda; from Mahmud's point of view the diplomatic atmosphere seemed to be ready for the last operation against Mehmet Ali. The two most significant figures in the European diplomacy had tacitly expressed that they were in favour of the Ottomans defending their territory with a retaliatory strike against the provocation of Mehmet Ali's unchecked army advances, and that that they had a right to intervene against Mehmet Ali after he had so blatantly violated the conditions of the treaty of Kütahya by attacking to his sovereign's territories. Furthermore, since 1826 Mahmud and his statesmen had been applying their utmost endeavours to the improvement of the new and inexperienced Ottoman Army, Asakir-i Mansure-i Muhammediye. Furthermore, now he had gained the European countries' support, and in particular with the efforts the British made after the treaty of Unkiar Skelessi to educate the Ottoman officers and enhance the ammunition of the Ottoman Army, Mahmud II had started to think that his army was now perhaps strong enough to beat his governor's army. His renewed opinion about his forces potency meant that in his mind's eye, this time was going to be completely different from the battles he had lost in Syria and in Konya in 1832. As a matter of fact Mahmud was not altogether unreasonable in thinking like this, since this time, he not only had on his side the support of the majority of the European countries, but also a much better trained and equipped army, by

${ }^{11}$ To find more information about Mahmud II' using the Treaty of Balta Limanı as a diplomatic weapon to solve Mehmet Ali Problem look at S. Demirbas, The Treaty of Balta Limanı's Role in Anglo-Ottoman Relations During The Mehmet Ali Problem, Journal of History School, 8(24), December 2015, pp.233-251. 
Mahmud Iı's Diplomatic Reforms and Final Ottoman Diplomatic Manoeuvres Before...

the virtue of all his and his statesmen's vigorous diplomatic efforts, played out between 1833 and 1839 .

\section{CONCLUSION}

Mahmud II's all the military and diplomatic efforts provided him with the confidence to confront Mehmet Ali as regards his continual breaches of the peace treaty. But in spite of Mahmud II's beliefs in his army's strength and capacity to beat his rebel governor's army, the Ottoman army suffered a resounding defeat on 24 June 1839 in Nizip, an Ottoman provincial town in SOutheastern Anatolia. This was a devastating blow, and plunged the Empire into a major crisis; however, Mahmud did not live long enough to hear about this devastating turn of events, as he died on July 1, 1839, only a few days before the news arrived in Istanbul. Despite the Sultan's death and the defeat of his army, Mehmet Ali could not advance his army any further because of the diplomatic pressure on him from other European countries. At this stage, it should be mentioned that some foreign scholars, such as Webster, have attributed this diplomatic success over Mehmet Ali to Palmerston's diplomatic ability. By way of illustration, Webster stated on this subject that;

"The triumph of Palmerston in 1840 was perhaps the greatest which he ever won in his long connection with foreign affairs... This result was obtained because Palmerston sought ends which in the long run even those who opposed him saw were necessary. The time was not ripe for a dissolution of the Ottoman Empire which would almost certainly have occurred if Palmerston had not had his way. This failure of Mahmud's final fling at his vassal, so disastrous in its results, would have deprived the Porte permanently of the rule of all the Aran-speaking lands, including the Holy Places, unless it had been rescued by European, mainly British, action." (Webster, 1951, p.621)

These determinations and views of the foreign scholars do not show the whole picture in all its aspects because nobody, including the Turkish historians, has ever described Mahmud II's and his diplomats' role in this diplomatic success story in winning the European powers, particularly Britain, around to their side via their vigorous diplomatic efforts during the process leading up to the Egyptian army's last decisive victory in Nizip. It was, partly at least, those diplomatic and political efforts of previous decade which now bore fruit. The Ottoman Empire was thought to be reformable by Palmerston, and he no longer thought it was going to fall apart; he was also determined not to repeat the mistakes of 1832/3. 


\section{Serkan DEMIRBAŞ}

However, examination of this intensive diplomatic period, 1833-1839, from the point of view of the Ottoman side is extremely critical. The Ottoman influence, under the leadership of Mahmud II, was in large part a strong factor determining the alteration of the attitude of the British, particularly Palmerston about this "Eastern Empire". This mission was not easy since this very same person, Palmerston, and the very same British politicians, had been thinking the exact opposite at the beginning of the 1830s about the Ottoman Empire to the way they now thought about the Empire in the second half of the 1830s. Charmley summarised very well the British position in 1831 on the Ottomans.

"Palmerston's initial stance on the Ottoman Empire was what one might have expected from the self-proclaimed inheritor of Canning's philhellene policy; he was, initially, firmly on the side of those who believed that the Ottoman Empire was doomed. In a letter to his old friend (now ambassador to France) Lord Granville, in 1831, he wrote: "The fact is that Turkey is rapidly falling the pieces. This need not imply that he, personally, wanted the Ottoman Empire to collapse, but there were certainly those in the government who did." (Charmley, 2002, p.82)

As it can be seen in these words of Charmley, although Palmerston was so pessimistic about the Ottoman Empire's ability to survive or even worse, some British politicians in the Cabinet even desired the Empire'dissolution. Later on, the main British policy had been to support the maintenance of the territorial integrity of this Eastern country with their all might. It is a fact that that this sea change, in the British policy respecting the Eastern affairs which came about in only a few years, would have been too great to be spontaneous.

It might be said that it is not necessary in this article to study diplomatic events after Mahmud II's death since the present literature has covered this in much detail. However, it should be mentioned that the last words of the article, assert that Mahmud's and his diplomats' contribution was considerable, and just as significant as that of Palmerston and Metternich. The Sultan's diplomatic efforts greatly assisted in bringing about the first result in 1839, stopping Mehmet Ali from going any further, and then the Convention of London, officially called the Convention for the Pacification of the Levant, signed in 1840 by the Ottoman Empire and the four European powers, Britain, Russia, Austria, Prussia, and Mehmet Ali. This convention was vital, and profitable for both the British and the Ottomans, because Mehmet Ali and the Russians lost almost everything that they had acquired between 1833 and 1839. This treaty would probably have evidenced to Mahmud II that all his diplomatic efforts had been well worth all his trouble, had he lived long enough to see this positive final phase of the long and 
Mahmud Iı's Diplomatic Reforms and Final Ottoman Diplomatic Manoeuvres Before...

difficult diplomatic process he had instigated to free his Empire from two big troubles; Mehmet Ali and Russia.

\section{KAYNAKÇA / REFERENCES}

\section{Archival Sources}

\section{T. C. Devlet Arşivleri Başkanlığı Osmanlı Arşivi (BOA)}

BOA, HAT., File No: 380 Document No: 20558 C, File No: 382 Document No: 20584, File No: 1179 Document No: 46569 J, File No: 1190 Document No:46879 001, File No: 381 Document No: 20567, File No: 685 Document No: 33266 H, File No: 737 Document No: 34965 E, File No: 697 Document No: 33630, File No: 737 Document No: 34969 G, File No: 828 Document No: 37478 A, File No: 828 Document No: 37482 A, File No: 828 Document No: 37490, File No: 829 Document No: 37498, File No: 829 Document No: 37500 B, File No: 830 Document No: 37506, File No: 829 Document No: 37502 B, File No: 381 Document No: 20579 H, File No: 382 Document No: 20592, File No: 452 Document No: 22409 C, File No: 831 Document No: 37519 A, File No: 831 Document No: 37519 B.

BOA, C., HR, File No: 152 Document No: 7569.

\section{Secondary Sources}

Charmley, J. (2002). Palmerston: artful dodger or babe of grace. T.G. Otte (Ed.), in The Makers of British Foreign Policy (p.75-97). Palgrave Macmillan.

Demirbas, S. (2015). The treaty of balta limanı's role in anglo-ottoman relations during the Mehmet Ali problem. Journal of History School,8(24), 233-251.

Demirbaş, S. (2016). A new perspective on the treaty of unkiar skelessi mahmud II's use of international diplomacy to resolve the mehmet ali problem, Eskişehir Osmangazi Üniversitesi Sosyal Bilimler Dergisi, 17(2), 1-16.

Findley, C.V. (2014). Osmanlı Imparatorluğu’nda Bürokratik Reform. Tarih Vakfi Yurt Yayınları.

Findley, C.V. (1972). The foundation of the Ottoman foreign ministry: The beginnings of bureaucratic reform under Selim III and Mahmud II. International Journal of Middle East Studies, 3(4), 388-416. 


\section{Serkan DEMİRBAS}

Findley, C.V. (1970). The legacy of tradition to reform: Origins of the ottoman foreign ministry. International Journal of Middle East Studies, 1(4), 334357.

Ortaylı, İ. (2009). İmparatorluğun En Uzun Yüzyılı. Timaş Yayınları.

Rodkey, F.S. (1929). Lord palmerston and the rejuvenation of Turkey 1830-41. The Journal of Modern History, 1(4), 570-593.

Turan, N.S. (2014). Imparatorluk ve Diplomasi. İstanbul Bilgi Üniversitesi Yayınları.

Webster, C. (1951). The Foreign Policy of Palmerston: 1830-1841: Britain, The Liberal Movement and The Eastern Question, Vol. I. G. Bell and Sons.

Zürcher, E.J. (2009). Modernleşen Türkiye’nin Tarihi. İletişim Yayıncılık.

\section{EXTENDED ABSTRACT}

Mahmud II initiated a massive reform programme in order to improve the social, economic, military and administrative circumstances of the Empire with the help of well trained statesmen. These reforms have been studied by numerous historians. Nevertheless, the narrative concerning the use of the diplomacy that was conducted by Mahmud II and his diplomats and that was seen as the only weapon to save the Empire from major international conflicts along with many other issues the Empire had to deal with, were either not narrated from an Ottoman perspective and not in a proper manner or it was done from a European viewpoint. "Orientalism" could be said to be one of the most important reasons for this bias against the Ottoman diplomacy of that era. This bias is most evident when it comes to the issue of Mehmed Ali Pasha of Egypt. This issue took place between 1831 and 1839. In spite of the big ambitions of the governor of Egypt, Mehmed Ali Pasha who wanted to give the house of Osman an end, the two military defeats (1832 Konya and 1839 Nizip) did not finish off the Empire. At this point, the following question comes to mind: what saved the Empire that had already become militarily vulnerable to collapse. The answer is simple: diplomacy. Most accounts of the Ottoman diplomacy of that era have always been one sided and Eurocentric due to some "orientalist" biases and prejudices. According to these narratives, after suffering some military defeats, Mahmud II and his diplomats just watched the diplomatic manoeuvres of the European powers in Ottoman lands and waited for the end without having any diplomatic plans and manoeuvres. They also portray Lord Palmerston as the sole architect 
Mahmud Iı's Diplomatic Reforms and Final Ottoman Diplomatic Manoeuvres Before...

of the 1840 Treaty of London that compensated the two military defeats and that extended the life of the Empire by another century.

However when we examine the instructions in Ottoman documents given by the Emperor to his diplomats residing in many European capitals and their efforts to follow them, it will be seen what kind of a role Mahmud II and his diplomats played in this diplomatic success. It will also be seen that the Emperor and his diplomats had a diplomatic goal and they launched a diplomatic campaign to reach that goal, and this was the background to the ensuing events seen as to the detriment of the Empire: the arrival in Istanbul of Russian troops after the 1832 Konya defeat, the 1833 Treaty of Hünkar Iskelesi, the 1838 Treaty of Baltalimani and finally the Battle of Nizip in 1839.

In this study a short introduction to the course of the institutional reforms in Ottoman diplomacy from Selim III to Mahmud II will be followed by a focus on the Empire's diplomatic manoeuvres prior to the Battle of Nizip that was itself an effort to bring the diplomatic campaign initiated by the Emperor and his men, to a successful end. 